\title{
Increased methylation of the cytosolic $20-k D$ protein is accompanied by liver regeneration in a hepatectomized rat
}

\author{
Soon-Young Kwon ${ }^{1 *}$, Sohee $\mathrm{Kim}^{2 *}$ \\ Kyounghwa Lee ${ }^{2}$, Tae Jin Kim ${ }^{2}$ \\ Seung-Hoon Lee ${ }^{1}$, Kyung-Mi Lee ${ }^{2}$ \\ and Gil Hong Park \\ ${ }^{1}$ Department of Otolaryngology-Head and \\ Neck Surgery \\ College of Medicine, Korea University \\ Ansan 425-707, Korea \\ ${ }^{2}$ Department of Biochemistry \\ College of Medicine, Korea University \\ Seoul 136-705, Korea \\ ${ }^{3}$ Corresponding author: Tel, 82-2-920-6182; \\ Fax, 82-2-928-4853; E-mail, ghpark@korea.ac.kr \\ *These authors contributed equally to this work \\ Accepted 30 January 2004
}

Abbreviations: ADMA, $N^{G} N^{G}$-dimethyl(asymmetric)arginine; AdoMet, S-adenosyl-L-methionine; CARM1, co-activator associated arginine methyltransferase 1; JBP1, Janus kinase binding protein 1; MBP, myelin basic protein; MMA, $N^{G}$-monomethylarginine, PRMT, protein arginine methyltransferase; SDMA, $N^{G} N^{\prime G}$-dimethyl(symmetric)arginine; UP1, unwinding protein 1

\begin{abstract}
Arginine methylation has been implicated in the signal transduction pathway leading to cell growth. Here we show that a regenerating rat liver following partial hepatectomy exhibited elevated methyltransferase activity as shown by increased methylation of a subset of endogenous proteins in vitro. The 20-kDa protein was shown to be a major cytosolic protein undergoing methylation in regenerating hepatocytes. Methylation of the $20-\mathrm{kDa}$ protein peaked at $1 \mathrm{~d}$ following partial hepatectomy, which gradually declined to a basal level within the next $14 \mathrm{~d}$. Likewise, methylation of exogenously added bulk histones followed the similar time kinetics as the $20-\mathrm{kDa}$ protein, reflecting time-dependent changes in methyltransferase activity in regenerating hepatocytes. Presence of exogenously added bulk histone in the in vitro methylation assay resulted in dose-dependent inhibition of methylation of the $20-\mathrm{kDa}$ protein. All the histone subtypes tested, histone $1,2 A, 2 B, 3$ or 4 , were
\end{abstract}

able to inhibit methylation of the $20-\mathrm{kDa}$ protein while addition of cytochrome C, a-lactalbumin, carbonic anhydrase, bovine serum albumin, and $g$ globulin minimally affected methylation of the $20-\mathrm{kDa}$ protein. Since methylation of the $20-\mathrm{kDa}$ protein preceded proliferation of hepatocytes upon partial hepatectomy, it is tempting to speculate that the methylated $20-\mathrm{kDa}$ protein by activated histone-specific methyltransferase may be involved in an early signal critical for liver regeneration.

Keywords: arginine N-methylation; cytosolic 20-kDa protein; histone; regenerating rat liver

\section{Introduction}

$\mathrm{N}$-methylation on arginine residues has been shown to occur in a variety of cellular processes including protein trafficking, protein-protein interaction, and various signal transduction pathways leading to cellular proliferation (Paik and Kim, 1980; McBride and Silver, 2001). Methylation of proteins is catalyzed by highly specific methyltransferases which transfer methyl group from S-adenosyl-L-methionine (AdoMet) to the guanidino nitrogen of arginine residues, generating $N^{G}$-monomethylarginine (MMA), $N^{G} N^{G}$-dimethyl (asymmetric) arginine (ADMA) and $N^{G} N^{\prime G}$-dimethyl (symmetric) arginine (SDMA) (Paik and Kim, 1980; Gary et al., 1996). Enzymes that mediate the transfer of methyl group, protein arginine methyltransferases (PRMT), have been cloned and named as PRMT1 (Lin et al., 1996; Tang et al., 2000), PRMT2 (Katsanis et al., 1997; Scott et al., 1998), PRMT3 (Tang et al., 1998), PRMT4 (co- activator associated arginine methyltransferase 1, CARM1) (Chen et al., 1999), PRMT5 (Janus kinase binding protein 1) (Pollack et al., 1999), and PRMT6 (Frankel et al., 2002). RNA-binding proteins, myelin basic protein, and histones are well known substrates for PRMTs. RNA-binding proteins which generate MMA and ADMA include hnRNP-A1 (Kumar et al., 1986; Kim et al., 1997), nucleolin (Lischwe et al., 1982), fibrillarin (Lischwe et al., 1985a; 1985b), the Sam68 Src-associated substrate (Bedford et al., 2000), poly(A)-binding protein II (Smith et al., 1999), the NF90 nuclear-binding factor (Tang et al., 2000), interleukin enhancer binding factor 3 (Tang et al., 2000) and the yeast Npl3 protein (Lee et al., 1996; Siebel and Guthrie, 1996). Myelin basic protein (Stoner, 1984) and proteins SmD1 and SmD3 (Frie- 
sen et al., 2001) are substrates known to produce SDMA. Once methylated, histones can induce transcriptional silencing at the heterochromatin sites while they can initiate transcription at the euchromatic loci (Bannister et al., 2002).

The PRMT activity was shown to be directly correlated with the degree of proliferation and thus, found to be elevated in highly proliferating tissues such as regenerating liver, developing fetal brain, rapidly growing hepatomas and continuously dividing HeLa cells (Paik et al., 1975; Paik and Kim, 1980). Recently, the 20-kDa cytosolic protein was found to be a major endogenous substrate undergoing in vitro arginine methylation in proliferating mammalian cells. Human cancer cell lines (HCT-48, HeLa cells, A549 and Hep G2) showed increased level of methylation in this $20-\mathrm{kDa}$ protein as compared to their normal counterparts, suggesting that increased methylation is associated with cellular proliferation and transformation ( $\mathrm{Gu}$ et al., 1999). The identity of this $20-\mathrm{kDa}$ protein is still not known, but addition of bulk histones completely suppressed methylation of $20-\mathrm{kDa}$ protein while addition of hnRNP-A1 partially inhibited the $20-\mathrm{kDa}$ methylation, indicating that these three proteins compete for the same protein methyltransferase (Park et al., 1997; Gu et al., 1999).

Since previous data showing increased methylation of the $20-\mathrm{kDa}$ protein were obtained from transformed cancer cell lines (Gu et al., 1999), it was of interest to determine if methylation events occur in more physiological settings. Our particular interest was to investigate signaling events involved in the process of liver regeneration. We now found that methylation of the $20-\mathrm{kDa}$ protein was increased in proliferating hepatocytes due to elevated methyltransferase activity, and that histones may play some regulatory roles in this process. Therefore, methylation events are commonly associated with cell proliferation under physiologic conditions.

\section{Materials and Methods}

\section{Reagents}

S-adenosyl-L-[methyl- $\left.{ }^{3} \mathrm{H}\right]$ methionine $\left(\left[{ }^{3} \mathrm{H}\right]\right.$ AdoMet; $60 \mathrm{Ci} /$ $\mathrm{mmol})$ was purchased from Amersham Pharmacia Biotech Inc. (NJ). Calf thymus histone II-AS (prepared by extraction in $1 \mathrm{M} \mathrm{NaCl}$, precipitation in water, followed by acid extraction, dialysis and lyophilization), myelin basic protein, cytochrome $\mathrm{C}$, a-lactalbumin, carbonic anhydrase, alcohol dehydrogenase, bovine serum albumin, g-globulin and S-adenosyl-Lhomocysteine were purchased from Sigma Chemical Co. (MO). Calf thymus histones 1, 2A, 2B, 3 and 4 were purchased from Roche Applied Science (Mannheim, Germany). Sodium dodecyl sulfate-polyacryl- amide gel electrophoresis (SDS-PAGE) reagents and LMW electrophoresis calibration kits were purchased from Bio-Rad Laboratories (CA).

\section{Partial hepatectomy}

Median and left lateral lobes (about $70 \%$ of liver) of 6 week-old Sprague Dawley rats were surgically removed according to the method approved by Institutional Review Board (day 0 ). Rats were then sacrificed at day $1,3,5,7,14,21$ and 28 following hepatectomy and the remaining (regenerating) liver (right lateral and caudate lobes) was harvested for analysis (Waynforth and Flecknell, 1992). At each time point, three rats were used for analysis.

\section{Preparation of cytosolic extracts}

All procedures were carried out at $4^{\circ} \mathrm{C}$ unless otherwise stated. Harvested liver was cut into small pieces and homogenized in 4 volumes of $0.32 \mathrm{M}$ sucrose containing $5 \mathrm{mM}$ potassium phosphate $(\mathrm{pH} 7.6)$, $5 \mathrm{mM}$ ethylenediaminetetraacetic acid, $1 \mathrm{mM}$ dithiothreitol, $1 \mathrm{mM}$ 2-mercaptoethanol and $0.5 \mathrm{mM}$ phenylmethylsulfonylfluoride. Homogenates were centrifuged at $100,000 \mathrm{~g}$ for $60 \mathrm{~min}$, and the supernatant was used as crude cytosolic extracts which contain endogenous enzymes and substrates of the liver ( $\mathrm{Gu}$ et al., 1999).

\section{In vitro methylation assay}

Methylation reaction was carried out by adding 5 $\mathrm{mCi}$ of $\left[{ }^{3} \mathrm{H}\right]$ AdoMet into $50 \mathrm{mg}$ of crude extracts of rat liver $(100,000 \mathrm{~g}$ supernatant) in a total volume of 50 $\mathrm{ml}$. Where indicated, $20 \mathrm{mM}$ of bulk histones (histone II-AS, Sigma) or their individual subtypes, histone 1, $2 \mathrm{~A}, 2 \mathrm{~B}, 3$ or 4 , were added to the mixture prior to assay. Alternatively, $20 \mathrm{mM}$ of myelin basic protein, cytochrome C, a-lactalbumin, carbonic anhydrase, alcohol dehydrogenase, bovine serum albumin, or bovine g-globulin, were added to the reaction mixture. S-adenosyl homocysteine, which specifically inhibits AdoMet-dependent methylation, was added at $0.8 \mathrm{mM}$ to the reaction mixture to inhibit methyltransferase activity. Reaction was carried out at $37^{\circ} \mathrm{C}$ for $30 \mathrm{~min}$, and stopped by adding $5 \times$ SDS-PAGE sample buffer (Park et al., 1997). Protein concentration was determined according to Bradford method (Bradford, 1976).

\section{Methylation analysis by SDS-PAGE and autoradiography}

The reaction mixture dissolved in SDS-PAGE sample buffer was loaded onto $15 \%$ polyacrylamide gels and run under constant current (20 mA) (Laemmli, 1970). The gel was stained with Coomassie Blue, soaked in 
Amplify solution (NAMP-100, Amersham), dried and exposed to Hyperfilm ${ }^{\mathrm{TM}}$ MP (Amersham) diagnostic film at $-70^{\circ} \mathrm{C}$ for 7 days. The density of radioactive bands were measured using Fujix-Bio-Imaging Analyzer BAS2500 (Fuji Photo Film).

\section{Results}

\section{Increased methylation activity in a regenerating rat liver as revealed by in vitro methylation assay}

Liver regeneration following partial hepatectomy in a rat involves initiation of proliferation and differentiation of the residual hepatic parenchymal stem cells. As a result, hepatectomized liver can restore the liver mass to its original size within 10-20 d (Waynforth and Flecknell, 1992). To determine the time course of liver regeneration, we measured the weight of the remaining liver at different days following partial hepatectomy. As shown in Figure 1, weight of the remaining liver (right lateral and caudate lobes) increased following partial hepatectomy (day 0 ) and reached the normal mass by $28 \mathrm{~d}$. By comparison, weight of right lateral and caudate lobes from age-matched non-

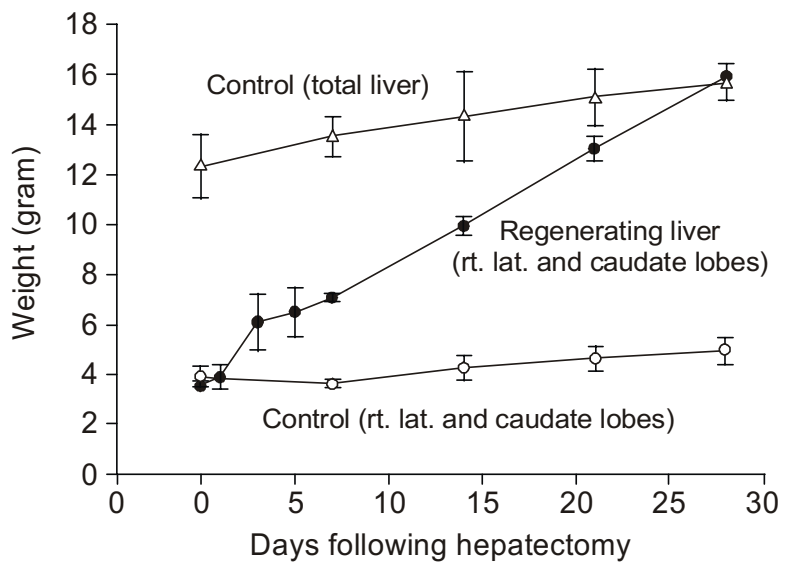

Figure 1. Liver regeneration following partial hepatectomy. Median and left lateral lobes of 6 week-old Sprague Dawley rats were removed at day 0 as described in Materials and Methods. Remaining right lateral and caudate lobes were removed at $0,1,3,5,7,14,21,28$ days following partial hepatectomy and their weight was measured (closed circle). As a control, the right lateral and caudate lobes were removed from age-matched normal rats and their weight was measured (open circle). Total liver mass was also measured from the control age-matched rats (open triangle), showing that partially hepatectomized liver restored its original mass within 28 days. At each time point, three rats were used for analysis.
A

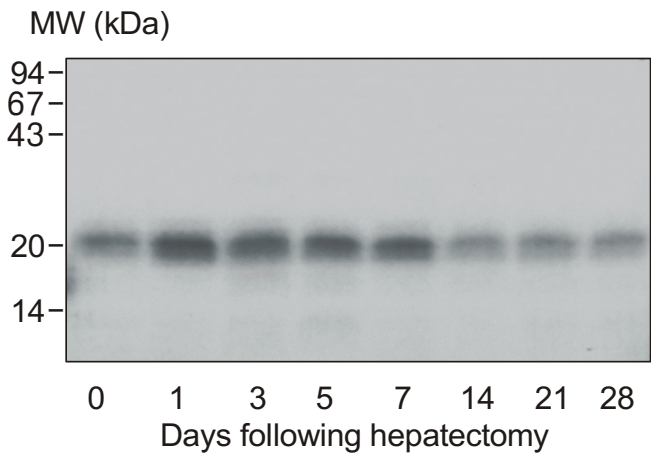

C

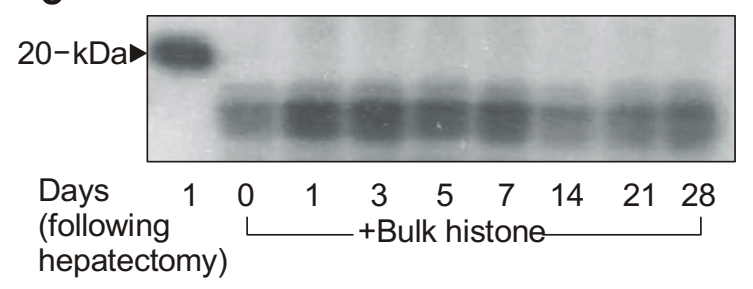

B

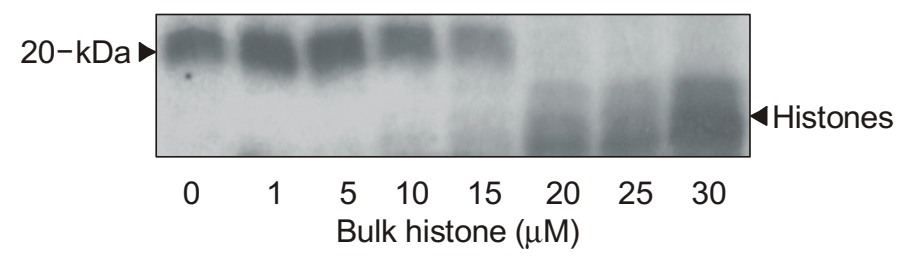

D

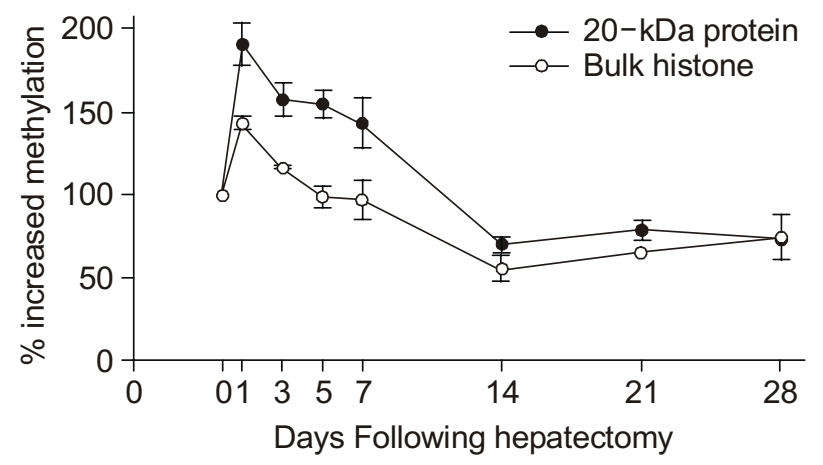

Figure 2. A $20-\mathrm{kDa}$ protein is a major substrate methylated by regenerating rat liver extracts. (A) Cytosolic extracts $(100,000 \mathrm{~g}$ for $60 \mathrm{~min}$ supernatants of whole cell extracts) were prepared from rat liver at $0,1,3,5,7,14,21,28$ days following partial hepatectomy. Equal amounts of protein $(50 \mathrm{mg})$ were incubated with Ado [methyl ${ }^{3} \mathrm{H}$ ]Met for $30 \mathrm{~min}$, and analyzed by SDS-PAGE and autoradiography. (B) Cytosolic extracts prepared from day 1 liver following hepatectomy were incubated with various doses of bulk histone and subjected to methylation assay. Numbers at the bottom indicate the concentration of bulk histone added to the reaction mixtures. (C) Twenty mM Bulk histone was added to the methylation assay mixture with the liver extracts prepared as in (A). (D) Changes of methylation on a $20-k D a$ protein $(A)$ and bulk histone (C) obtained from three individual experiments were plotted over time. The level of methylation was measured by densitometry and the degree of methylation was normalized to that observed in cell extracts prepared from non-hepatectomized liver (day 0). Error bars indicate \pm SD. 
hepatectomized mice did not change significantly over time. Similarly, weight of entire liver from non-hepatectomized mice did not change significantly. These data indicate that the remaining liver proliferated and differentiated to restore its original mass. To examine if regenerating liver cells undergo changes in methylation status, crude cytosolic extracts were prepared at different days post-hepatectomy and subjected to an in vitro methylation assay. As shown in Figure $2 \mathrm{~A}$, the major protein appearing in the gel following in vitro methylation assay was a band migrating at $20-\mathrm{kDa}$. Methylation of this $20-\mathrm{kDa}$ protein peaked at day 1 , which then subsequently declined to a basal level by $14 \mathrm{~d}$ post-hepatectomy. Basal level of methylation was maintained after $14 \mathrm{~d}$ till $28 \mathrm{~d}$. Interestingly, when bulk histone (histone II-AS) prepared from calf thymus was added as an exogenous substrate to the reaction mixture containing day 1 liver extracts, methylation of a $20-\mathrm{kDa}$ protein was dose-dependently inhibited (Figure 2B). Maximal inhibition occurred at $20 \mathrm{mM}$ of bulk histone. Interestingly, while methylation of a $20-\mathrm{kDa}$ protein is inhibited, methylation of bulk histone becomes evident, suggesting that histones can function as a competitive inhibitor for methyltransferases responsible for methylation of a $20-\mathrm{kDa}$ protein. Inhibition of the $20-\mathrm{kDa}$ protein methylation by histones was evident with all samples prepared from different days post hepatectomy (Figure 2C). Similar to a 20-kDa protein, methylation of exogenously added bulk histone followed the same kinetic during the course of liver regeneration, which reflects time-dependent changes in methyltransferase activity post hepatectomy (Figure $2 \mathrm{C}$ and $\mathrm{D})$. The fact that methylation of a $20-\mathrm{kDa}$ protein was completely inhibited by histones and that histones themselves became methylated by liver extracts strongly suggests that a $20-\mathrm{kDa}$ protein might have been methylated by histone-specific methyltransferases in the cytosolic extracts of regenerating hepatocytes. Since increased methylation of the $20-\mathrm{kDa}$ protein was also observed in proliferating cancer cell lines (Gu et al., 1999), it is tempting to speculate that methylation of a $20-\mathrm{kDa}$ protein is associated with signaling events leading to the proliferation of hepatocytes.

Individual histone subtypes, H1, H2A, H2B, H3, or $\mathrm{H} 4$, can all suppress methylation of

\section{a 20-kDa protein}

Since bulk histone used as an inhibitor of methylation in our assay contained various subtypes of histones, we next attempted to determine the identity of histones responsible for inhibiting methylation of a $20-\mathrm{kDa}$ protein. Figure 3 shows that methylation of a $20-k D a$ protein was completely inhibited by $S-$ adenosyl homocysteine (SAH), a well known inhibitor of methyltransferases (Figure 3A, lane 2) (Gu et al., 1999). Interestingly, addition of bovine serum albumin (BSA) also partially inhibited methylation of a $20-\mathrm{kDa}$ protein in this particular blot (Figure $3 A$, lane 3 ). However, this inhibition was not statistically significant when data were averaged from three individual experiments as shown in a bar graph in Figure 3B. Addition of bulk histone (Figure $3 \mathrm{~A}$, lane 4, H2AS) completely inhibited methylation of a $20-\mathrm{kDa}$ protein, similar to that observed in Figure 2 ( $B$ and $C$ ). When individual isoforms of histones were added to the reaction mixture, all the histone subclasses tested, histone 1, 2A, 2B, 3 or 4 , showed almost complete inhibition of the $20-\mathrm{kDa}$ protein methylation, indicating that the $20-\mathrm{kDa}$ protein and all the subclasses of histones share a common methylation motif recog-
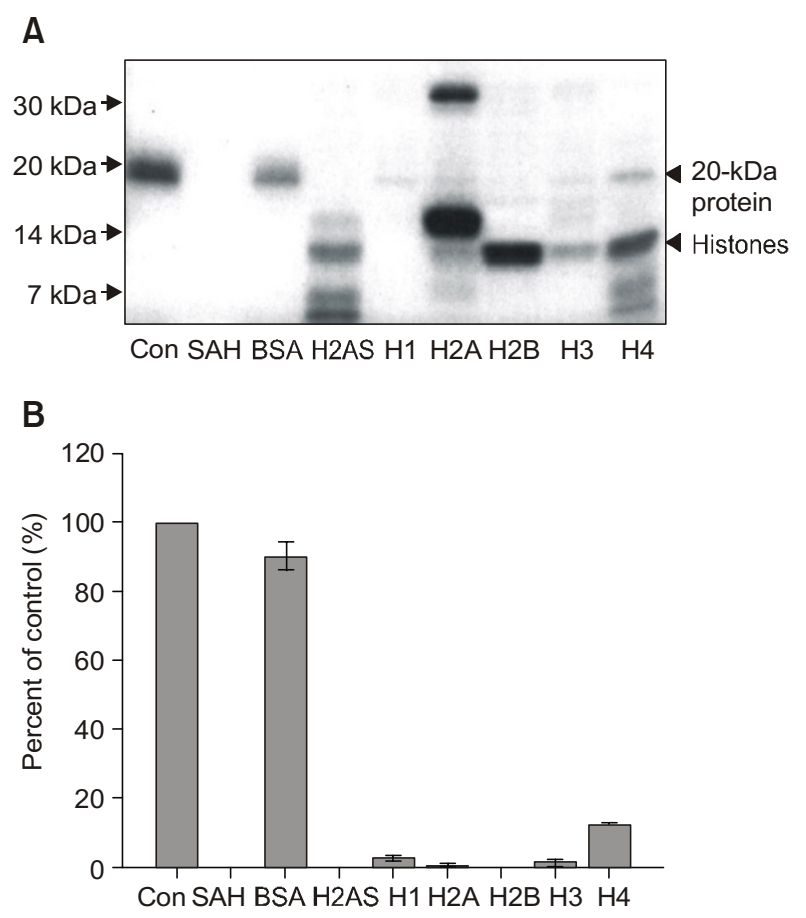

Figure 3. Effects of individual histone isotypes on methylation of the $20-\mathrm{kDa}$ protein. (A) Cytosolic extracts prepared from day 1 liver following hepatectomy were incubated with Ado[methyl- $\left.{ }^{3} \mathrm{H}\right] \mathrm{Met}$ in the presence of $20 \mathrm{mM}$ of bulk histone (H2AS), or individual subtypes of histones, H1, H2A, H2B, H3, or H4 (lane 4-9). Lane 1, Con, indicates control without any exogenously added proteins. Addition of $0.8 \mathrm{mM}$ $\mathrm{SAH}$, an inhibitor of methyltransferases, completely inhibited methylation of a $20 \mathrm{kDa}$ protein (lane2). Twenty $\mathrm{mM} \mathrm{BSA}$ (bovine serum albumin), added as a negative control (lane 3), resulted in slight reduction of methylation in the $20-\mathrm{kDa}$ protein in this blot, however, it was not statistically significant when data are averaged from three individual experiments as shown in a bar graph in (B). (B) The bands of a $20 \mathrm{kDa}$-protein from three independent experiments were measured using densitometer and their averages were calculated as a percentage as compared to the control value. Error bars indicate $\pm S D$. 
A

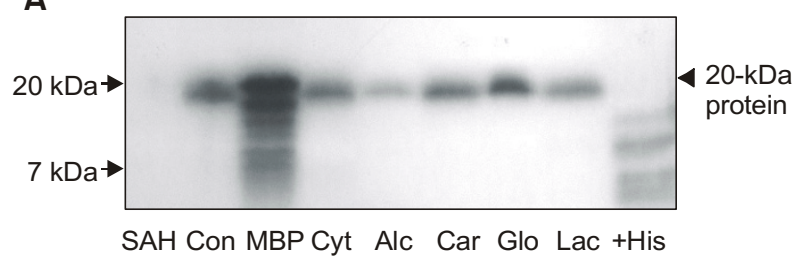

B

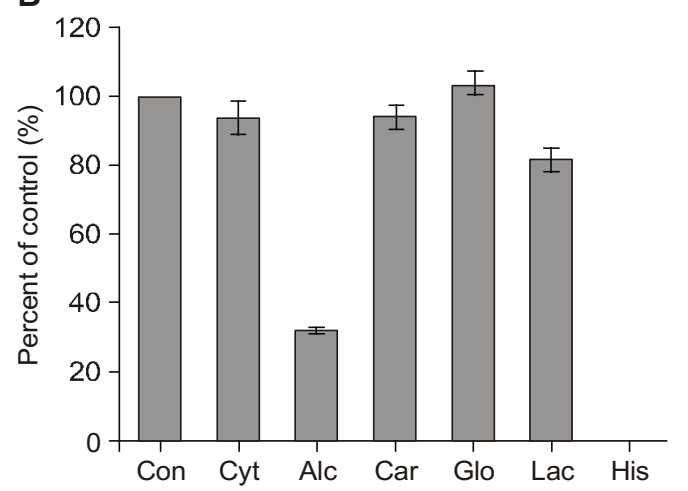

Figure 4. Effects of various proteins on methylation of a $20-\mathrm{kDa}$ protein. (A) Day 1 liver cytosolic extracts were incubated with Ado[methyl- ${ }^{3} \mathrm{H}$ ]Met in the presence of $20 \mathrm{mM}$ myelin basic protein (MBP, lane3), cytochrome C (Cyt, lane 4), alcohol dehydrogenase (Alc, lane 5), carbonic anhydrase (Car, lane 6), g globulin (Glo, lane 7), a-lactalbumin (Lac, lane 8), or bulk histone (His, lane 9). S-adenosyl homocysteine (SAH, lane 1) was added as a transmethylation inhibitor. Control (Con, lane 2) indicates no addition of exogenous proteins or agents. Reactions were subjected to SDSPAGE and autoradiography. (B) The bands of a $20 \mathrm{kDa}$-protein from three independent experiments were measured using densitometer and their averages were calculated as a percentage as compared to the control value. Error bars indicate $\pm S D$.

nized by a methyltransferase (Figure $3 A$, lane 5-9). Inhibition of a $20-\mathrm{kDa}$ protein methylation by histones was more noticeable when the percent density change of a $20-\mathrm{kDa}$ protein was averaged from three different experiments and plotted as a bar graph (Figure 3B). Among the subtypes of histones tested, histone $\mathrm{H} 4$ was the weakest inhibitor for competing with a $20-\mathrm{kDa}$ protein. By contrast, cytochrome C, carbonic anhydrase, g-globulin, and a-lactalbumin had no significant effect on the methylation of a $20-\mathrm{kDa}$ protein (Figure 4A, lane 4, 6, 7, 8). Interestingly, alcohol dehydrogenase partially inhibited methylation of the $20-\mathrm{kDa}$ protein (Figure 4A, lane 5 ), indicating that the protein is a weak substrate for the $20-k D a$ protein-specific methyltransferase. Myelin basic protein, a well known methyl acceptor (Chou et al., 1976), became methylated by endogenous methyltransferases present in the cytosolic extracts, however, it was difficult to conclude if MBP inhibited methylation of a $20-\mathrm{kDa}$ protein since MBP comigrated with a $20-\mathrm{kDa}$ protein on the gel (Figure $4 \mathrm{~A}$, lane 3). These data suggest that a methyltransferase responsible for methylating a $20-\mathrm{kDa}$ protein possesses distinct substrate specificity. Taken together, these data demonstrate that a protein arginine methyltransferase present in the cytosol becomes activated upon partial hepatectomy and may participate in the early signaling pathway leading to liver regeneration.

\section{Discussion}

Post-translational protein methylation induced by increased methyltransferase activity has been observed in proliferating tissues and cancer cell lines (Paik et al., 1975; Paik and Kim, 1980). Recently, a 20-kDa protein present in the cytosol of various human transformed cell lines was found to be the major substrate for activated methyltransferases (Park et al., 1997; Gu et al., 1999). In this study, we examined if proliferating hepatocytes following partial hepatectomy showed increased methylation of the $20-\mathrm{kDa}$ protein. We found that the $20-k D a$ protein was the major substrates that underwent methylation by activated methyltransferases in regenerating liver hepatocytes. Whether the changes in methylation of a $20-\mathrm{kDa}$ protein contributes to the liver regeneration is not clear at present. However, the transient increase in protein methylation associated with proliferation of hepatocytes allows us to speculate that activation of methyltransferases and subsequent methylation may play a critical role in transducing its signal to downstream events leading to DNA synthesis and cell proliferation.

Arginine methylation has been shown to be involved in various signaling pathways. At present, 6 forms of arginine methyltransferases are cloned; PRMT1-6. PRMT1 has been shown to be involved in the early signaling pathway via associating with TIS21 immediate-early gene, leukemia-associated BTG1 gene (Lin et al., 1996), the interleukin enhancer binding factor 3 (Tang et al., 2000), and the interferon $\mathrm{a} / \mathrm{b}$ receptor (Abramovich et al., 1997; Kim et al., 2003). PRMT1 was also shown to be involved in the signaling of nerve growth factor and regulate neurite outgrowth (Cimato et al., 1997). PRMT4/CARM1 has been shown to interact with $\mathrm{p} 160$ family of nuclear hormone receptor coactivators and enhance transcriptional activation, presumably via methylation of histone H3 (Chou et al., 1999). PRMT1, like PRMT4, can also bind p160, and these two PRMTs have been shown to act synergistically to enhance reporter gene activation by nuclear receptors (Koh et al., 2000). PRMT5/JBP1 was shown to be required for signaling of the interferon receptor to downstream Stat activation (Pollack et al., 1999).

Our data show that bulk histone as well as histone 
$1,2 \mathrm{~A}, 2 \mathrm{~B}, 3$ and 4 were potent inhibitors of the cytosolic $20-\mathrm{kDaa}$ protein methylation. $\mathrm{IC}_{50}$ of bulk histones was about $10 \mathrm{mM}$ and those of each subclass of histones appeared to have similar values. These data suggests that the $20-\mathrm{kDa}$ protein and histones compete for the same methyltransferase. This can be possible if both histones and the $20-\mathrm{kDa}$ protein possess the common methylation motif, such as GAR domain containing the multiple potential RGG motifs in hnRNP proteins (Dreyfuss et al., 1993). To support this, the major arginine methylation products of both $20-\mathrm{kDa}$ protein and histones were found to be ADMA and MMA (Rajpurohit et al., 1992; Park et al., 1997). Indeed, PRMT1, PRMT4 and PRMT6 have been demonstrated to have histone methyltransferase activity (McBride and Silver, 2001). PRMT1 and PRMT4 were shown to function as transcriptional coactivators in vivo by methylating histone $\mathrm{H} 4$ and histone $\mathrm{H} 3$, respectively (Chen et al., 1999; Wang et al., 2001), while PRMT6 was able to methylate histones $\mathrm{H} 2 \mathrm{~A}$ and $\mathrm{H} 4$ in an in vitro methylation reaction (Pollack et al., 1999). However, PRMT1, PRMT4/CARM1 and PRMT6, when tagged with green fluorescence protein (GFP), were all shown to be localized in the nucleus. Thus, the PRMT responsible for methylation of both $20-k D a$ protein and histones in the cytoplasm of hepatocytes may be distinct from those listed above. Therefore, it is tempting to speculate that a novel PRMT may exist in the cytosol, which regulate methylation of a $20-\mathrm{kDa}$ protein. In support of this idea, the $20-\mathrm{kDa}$ proteins were neither found to be present nor methylated in the nuclear fraction (Park et al., unpublished results) where histones reside. Therefore, although histones can be potent competitor for PRMTs in vitro, they are not likely to compete with $20-\mathrm{kDa}$ proteins for binding to nuclear PRMTs. Since both histones and PRMTs responsible for methylating histones are present in the nucleus, it will be interesting to see if $20-\mathrm{kDa}$ proteins become translocated into the nucleus upon methylation, where they can compete with histones for further methylation by PRMTs.

In our study, methylation of both cytosolic and nuclear proteins was detected in the absence of pretreatment of cells with endogenous methyltransferase inhibitors, such as adenosine dialdehyde. However, previous reports using human lymphoblastoid cells showed that methylation was only observed when cells were pretreated with adenosine dialdehyde to obtain hypomethylated state of endogenous substrates. In that study, proteins migrating between 29 and $90 \mathrm{kDa}$ were shown to be methylated by endogenous cytosolic PRMTs (Li et al., 1998). Similarly, RNase treatment of RAT1 cell extracts resulted in methylation of hnRNP A1 and a series of cellular proteins running between $34-$ and $55-\mathrm{kDa}$, which could be catalyzed by PRMT1 and PRMT3 (Frankel and Clarke, 1999).
These data suggested that substrates were constantly associated with RNAs, which inhibited the access of these proteins to methyltransferases. Since our study indicates that the cytosolic $20-\mathrm{kDa}$ protein became methylated in the absence of pretreatment to enhance in vitro substrate methylation, these proteins may represent the true physiologic substrates undergoing methylation and thus, be involved in early signaling events leading to cell proliferation.

At present, the identity of the cytosolic $20-\mathrm{kDa}$ protein is not known. However, our preliminary data show that this $20-\mathrm{kDa}$ protein co-migrates with UP1, a shortened derivative of hnRNP A1 (aa 1-196) (Kumar et al., 1986). Furthermore, its methylation is blocked by oligopeptide spanning amino acids 187-196 of UP1 that contains a methylation site, Arg 193, suggesting that this protein may indeed be UP1. Since hnRNP A1 and histones were previously shown to compete for the same PRMT (Rajpurohit et al., 1994), identifying UP1 as another substrate for PRMTs adds more complexity of methylation events. UP1 has been shown to bind to DNA carrying single-stranded telomeric extensions at the $3^{\prime}$ terminus and protects telomeric sequences against degradation by endo- and exonucleases (Dallaire et al., 2000). Furthermore, recent studies have demonstrated that overexpression of UP1 extends life of primary porcine fetal fibroblasts in culture by preventing telomere shortening (Mir et al., 2003). Thus, it is tempting to speculate that UP1 becomes methylated upon proliferating stimuli in a regenerating liver. Further studies are under way to examine this possibility.

\section{Acknowledgment}

This work was supported by the research grant from Ministry of Education, Republic of Korea (1998-001F00034).

\section{References}

Abramovich C, Yakobson B, Chebath J, Revel M. A proteinarginine methyltransferase binds to the intracytoplasmic domain of the IFNAR1 chain in the type I interferon receptor. EMBO J 1997;16:260-6

Bannister AJ, Schneider R, Kouzarides T. Histone methylation: Dynamic or static? Cell 2002;109:801-6

Bedford MT, Frankel A, Yaffe MB, Clarke S, Leder P, Richard $S$. Arginine methylation inhibits the binding of proline-rich ligands to Src homology3, but not ww, domains. J Biol Chem 2000;275:16030-6

Bradford MM. A rapid and sensitive method for the quantitation of microgram quantities of protein utilizing the principle of protein-dye binding. Anal Biochem 1976;72:248-54

Chen D, Ma H, Hong H, Koh SS, Huang S, Schurter BT, 
Aswad DW, Stallcup MR. Regulation of transcription by a protein methyltransferase. Science 1999;284:2174-7

Chou FC-H, Chou C-HJ, Shapira R, Kibler RF. Basis of microheterogeneity of myelin basic protein. J Biol Chem 1976;251: 2671-9

Cimato TR, Ettinger MJ, Zhou X, Aletta JM. Nerve growth factor-specific regulation of protein methylation during neuronal differentiation of PC12 cells. J Cell Biol 1997;138:1089103

Dallaire F, Dupuis S, Fiset S, Chabeau B. Heterogeneous nuclear ribonuleoprotein $A$ : and UP1 protect mammalian telomeric repeats and modulate telomere replication in vitro. J Biol Chem 2000;275:14509-16

Dreyfuss G, Matubis MJ, Pino/Roma S, Burd CG. HnRNP proteins and the biogenesis of mRNA. Ann Rev Biochem 1993;62:289-321

Frankel A, Clarke S. RNase treatment of yeast and mammalian cell extracts affects in vitro substrate methylation by type I protein arginine N-methyltransferases. Biochem Biophys Res Comm 1999;259:391-400

Frankel A, Yadav N, Lee J, Branscombe TL, Clarke S, Bedford MT. The novel human protein arginine $\mathrm{N}$-methyltransferase PRMT6 is a nuclear enzyme displaying unique substrate specificity. J Biol Chem 2002;277:3537-43

Friesen WJ, Massenet S, Paushkin S, Wyce A, Dreyfuss G. SMN, the product of the spinal muscular atrophy gene, binds preferentially to dimethylarginine-containing protein targets. Mol Cell 2001;7:1111-7

Gary JD, Lin WJ, Yang MC, Herschman HR, Clarke S. The predominant protein-arginine methyltransferase from Saccharomyces cerevisiae. J Biol Chem 1996;271:12585-94

Gu H, Park SH, Park GH, Lim IK, Lee HW, Paik WK, Kim $S$. Identification of highly methylated arginine residues in an endogenous $20-\mathrm{kDa}$ polypeptide in cancer cells. Life Sci 1999;65:737-45

Katsanis N, Yaspo M-L, Fisher EMC. Identification and mapping of a novel human gene, HRMT1L1, homologous to the rat protein arginine $\mathrm{N}$-methyltransferase 1 (PRMT1) gene, Mamm. Genome 1997;8:526-9

Kim S, Merrill BM, Rajpurohit R, Kumar A, Stone KL, Papov VV, Schneider JM, Szer W, Wilson SH, Paik WK, Williams $K R$. Identification of $N^{G}$-methylarginine residues in human heterogeneous RNP protein A1:Phe/Gly-Gly-Gly-Arg-Gly-GlyGly/Phe is a preferred recognition motif. Biochemistry 1997; 36:5185-91

Kim SW, Oh HM, Kim BS, Chung HT, Han WC, Kim EC, Kim TH, Seo GS, L JH, Nah YH, Jung JC, Choi SC, Jun $C D$. Soluble factor from tumor cells induces heme oxygenase-1 by a nitric oxide-independent mechanism in murine peritoneal macrophages. Exp Mol Med 2003;35:53

Koh SS, Chen D, Lee YH, Stallcup MR. Synergistic enhancement of nuclear receptor function by $\mathrm{p} 160$ coactivators and two coactivators with protein methyltransferase activities. J Biol Chem 2000;276:1089-98

Kumar A, Williams KR, Szer W. Purification and domain structure of core hnRNP proteins $A 1$ and $A 2$ and their relationship to single-stranded DNA-binding proteins. J Biol
Chem 1986;261:11266-73

Laemmli VK. Cleavage of structural proteins during the assembly of the head of bacteriophage T4. Nature 1970;227: 680-5

Lee MS, Henry M, Silver PA. A protein that shuttles between the nucleus and the cytoplasm is an important mediator of RNA export. Genes Dev 1996;10:1233-46

Li C, Ai L-S, Lin C-H, Hsieh M, Li Y-C, Li S-Y. Protein NArginine methylation in adenosine dialdehyde-treated lymphoblastoid cells. Arch Biochem Biophys 1998;351:53-9

Lin WJ, Gary JD, Yang MC, Clarke YS, Herschman HR. The mammalian immediate-early TIS21 protein and the leukemiaassociated BTG1 protein interact with a protein-arginine $\mathrm{N}$ methyltransferase. J Biol Chem 1996;271:15034-44

Lischwe MA, Roberts KD, Yeoman LC, Busch H. Nucleolar specific acidic phosphoprotein $\mathrm{C} 23$ is highly methylated. J Biol Chem 1982;257:14600-2

Lischwe MA, Ochs RL, Reddy R, Cook RG, Yeoman LC, Tan EM, Reichlin M, Busch H. Purification and partial characterization of a nucleolar scleroderma antigen $(\mathrm{Mr}=34,000$; $\mathrm{pl}, 8.5)$ rich in $\mathrm{N}^{\mathrm{G}}, \mathrm{N}^{\mathrm{G}}$-dimethylarginine. J Biol Chem 1985b; 260:14304-10

Lischwe MA, Cook RG, Ahn YS, Yeoman LC, Busch $H$. Clustering of glycine and $N^{G}, N^{G}$-dimethylarginine in nucleolar protein C23. Biochemistry 1985a;24:6025-8

McBride AE, Silver PA. State of the Arg:protein methylation at arginine comes of age. Cell 2001;106:5-8

Mir B, Tanner N, Chaudhary BP, Piedrahita JA. UP1 extends life of primary porcine fetal fibroblasts in culture. Cloning Stem Cells 2003;5:143-8

Paik WK, Kim S, Ezirike J, Morries HP. S-adenosylmethionine: protein methyltransferases in hepatomas. Cancer Res 1975;35:1159-63

Paik WK, Kim S. Enzymology of protein methylation. In: Protein methylation: Series of Monographs, Vol. 1 (Paik WK, Kim S eds), 1980, 112-41, John Wiley \& Sons, New York, NY

Park SH, Park GH, Gu H, Hwang W-I, Lim IK, Paik WK, Kim S. Heterogeneous nuclear RNP protein A1-arginine methylation during HCT-48 cell cycle. Biochem Mol Biol Int 1997;42:657-66

Pollack BP, Kotenko SV, He W, Izotova LS, Barnoski BL, Pestka SJ. The human homologue of the yeast proteins Skb1 and Hsl7p interacts with Jak kinases and contains protein methyltransferase activity. J Biol Chem 1999;274: 31531-42

Rajpurohit R, Paik WK, Kim S. Enzymatic methylation of heterogeneous nuclear ribonucleoprotein in isolated liver nuclei. Biochim Biophys Acta 1992;1122:183-8

Rajpurohit R, Lee SO, Park JO, Paik WK, Kim S. Enzymatic methylation of recombinant heterogeneous nuclear RNP protein A1. Dual substrate specificity for S-adenosylmethionine: histone-arginine N-methyltransferase. J Biol Chem 1994;269: 1075-82

Scott $H$, Antonarakis S, Lalioti M, Rossier C, Silver P, Henry $M$. Identification and characterization of two putative human 
arginine methyltransferases (HRMT1L1 and HRMT1L2). Genomics 1998;48:330-40

Siebel CW, Guthrie C. The essential yeast RNA binding protein Npl3p is methylated. Proc Natl Acad Sci USA 1996; 93:13641-6

Smith J, Rucknage P, Schierhorn A, Tang J, Nemeth A, Linder M, Herschman HR, Wahle F. Unusual sites of arginine methylation in poly (A)-binding protein II and in vitro methylation by protein arginine methyltransferases PRMT1 and PRMT3. J Biol Chem 1999;274:13229-34

Stoner GLJ. Predicted folding of beta-structure in myelin basic protein. Neurochem 1984;43:433-47

Tang J, Gary J, Clarke S, Herschman HR. PRMT3, a type I protein arginine $\mathrm{N}$-methyltransferase that differs from PRMT1 in its oligomerization, subcellular localization, substrate specificity, and regulation. J Biol Chem 1998;273:16935-45

Tang J, Kao PN, Herschman HR. Protein-arginine methyltransferase $\mathrm{I}$, the predominant protein-arginine methyltransferase in cells, interacts with and is regulated by interleukin enhancer-binding factor 3. J Biol Chem 2000;275:19866-76

Wang $H$, Huang $Z-Q$, Xia $L$, Feng $Q$, Erdjument-Bromage $\mathrm{H}$, Strahl BD, Briggs SD, Allis CD, Wong J, Tempst $\mathrm{P}$, Zhang $\mathrm{Y}$. Methylation of histone $\mathrm{H} 4$ at arginine 3 facilitating transcriptional activation by nuclear hormone receptor. Science 2001;293:853-7

Waynforth HB, Flecknell PA. Hepatectomy. In Experimental and surgical technique in the rat, 2nd Ed, (Waynforth $H B$, Flecknell PA, eds), 1992, 241-8, Academic Press Ltd., London 